\title{
Planktic foraminifer and coccolith contribution to carbonate export fluxes over the central Kerguelen Plateau
}

\author{
M. Rembauville ${ }^{\mathrm{a}, *}$, J. Meilland ${ }^{\mathrm{b}}$, P. Ziveri ${ }^{\mathrm{c}, \mathrm{d}}$, R. Schiebel ${ }^{\mathrm{b}, \mathrm{e}}$, S. Blain ${ }^{\text {a }}$, I. Salter ${ }^{\mathrm{a}, \mathrm{f}}$ \\ a Sorbonne Universités, UPMC Univ Paris 06, CNRS, Laboratoire d'Océanographie Microbienne (LOMIC), Observatoire Océanologique, F-66650 Banyuls/mer, \\ France \\ ${ }^{\mathrm{b}}$ Université d'Angers, UMR CNRS 6112, LPG-BIAF-Bio-Indicateurs Actuels et Fossiles, 2 Boulevard Lavoisier, Angers 49045, France \\ ' Universitat Autònoma de Barcelona, ICREA-ICTA, Edifici Z, Carrer de les columnes s/n, E-08193 Bellaterra, Barcelona, Spain \\ ' Catalan Institution for Research and Advanced Studies, ICREA, Catalonia, Barcelona 08010, Spain \\ e Max-Planck-Institute for Chemistry, Hahn-Meitner-Weg 1, 55128 Mainz, Germany \\ ${ }^{\mathrm{f}}$ Alfred Wegener Institute, Helmholtz Centre for Polar and Marine Research, Am Handelshafen 12, 27570 Bremerhaven, Germany
}

\section{A R T I C L E I N F O}

\section{Article history:}

Received 22 November 2015

Received in revised form

19 February 2016

Accepted 24 February 2016

Available online 26 February 2016

Keywords:

Foraminifer

Coccoliths

Export

Carbonate counter-pump

Kerguelen Plateau

Southern Ocean

\begin{abstract}
A B S T R A C T
We report the contribution of planktic foraminifers and coccoliths to the particulate inorganic carbon (PIC) export fluxes collected over an annual cycle (October 2011/September 2012) on the central Kerguelen Plateau in the Antarctic Zone (AAZ) south of the Polar Front (PF). The seasonality of PIC flux was decoupled from surface chlorophyll $a$ concentration and particulate organic carbon (POC) fluxes and was characterized by a late summer (February) maximum. This peak was concomitant with the highest satellite-derived sea surface PIC and corresponded to a Emiliania huxleyi coccoliths export event that accounted for $85 \%$ of the annual PIC export. The foraminifer contribution to the annual PIC flux was much lower (15\%) and dominated by Turborotalita quinqueloba and Neogloboquadrina pachyderma. Foraminifer export fluxes were closely related to the surface chlorophyll $a$ concentration, suggesting food availability as an important factor regulating the foraminifer's biomass. We compared size-normalized test weight (SNW) of the foraminifers with previously published SNW from the Crozet Islands using the same methodology and found no significant difference in SNW between sites for a given species. However, the SNW was significantly species-specific with a threefold increase from T. quinqueloba to Globigerina bulloides. The annual PIC:POC molar ratio of 0.07 was close to the mean ratio for the global ocean and lead to a low carbonate counter pump effect $(\sim 5 \%)$ compared to a previous study north of the PF (6-32\%). We suggest that lowers counter pump effect south of the PF despite similar productivity levels is due to a dominance of coccoliths in the PIC fluxes and a difference in the foraminifers species assemblage with a predominance of polar species with lower SNW.
\end{abstract}

(c) 2016 Elsevier Ltd. All rights reserved.

\section{Introduction}

The Southern Ocean is the largest high nutrient, low chlorophyll (HNLC, Minas et al., 1986) area of the global ocean (Martin et al., 1990; Minas and Minas, 1992). Downstream of Subantarctic island plateaus, iron input from shelf sediments and glacial melt water can alleviate iron limitation and support large scale and long-lasting phytoplankton blooms (Blain et al., 2001, 2007; Pollard et al., 2007; Tarling et al., 2012). These blooms are dominated by diatoms (Armand et al., 2008; Korb et al., 2008; Quéguiner, 2013) that respond to high macronutrient concentrations, marked turbulence, deep mixed layer depths and usually moderate light

\footnotetext{
* Corresponding author.

E-mail address: rembauville@obs-banyuls.fr (M. Rembauville).
}

levels (Smetacek, 1985; Boyd, 2002; Strzepek et al., 2012). Diatom blooms result in a major contribution of biogenic silica to biomineral production of Southern Ocean waters, although biogenic production of calcium carbonate by calcifying planktonic organisms such as coccolithophores, foraminifers and pteropods can also occur.

Although neglected for a long time, the presence of coccolithophores in the Southern Ocean has been diagnosed based on an increasing number of direct observations (Winter et al., 2014) and the development of remote sensing methods (Balch et al., 2005, 2011, 2014). Southern Ocean coccolithophore populations are dominated by the cosmopolitan species Emiliania huxleyi (Saavedra-Pellitero et al., 2014; Winter et al., 2014) that is thought to be the major component of the "great calcite belt" observed in the vicinity of the Subantarctic Front (SAF) and Polar Front (PF) 
(Balch et al., 2014). Several studies have reported modern planktic foraminifer abundances and fluxes in the Southern Ocean from net tows (Asioli and Langone, 1997; Mortyn and Charles, 2003; Bergami et al., 2009; Meilland, 2015) and sediment traps (Donner and Wefer, 1994; King and Howard, 2003; Northcote and Neil, 2005; Salter et al., 2014). Foraminifer assemblages are characterized by a southward dominance of polar species Neogloboquadrina pachyderma. In a review, Hunt et al., (2008) compiled pteropod abundance in the Southern Ocean and reported a switch from a dominance of Limacina retroversa australis north of the PF to Limacina helicina antarctica south of the PF.

The presence of calcareous organisms has important implications not only for food web ecology of the Southern Ocean, but also for the cycling of carbon between the atmospheric, oceanic, and sedimentary reservoirs on various climatically relevant timescales. Two distinct carbon pumps operate to cycle carbon trough these different reservoirs (Volk and Hoffert, 1985). The soft tissue pump transfers particulate organic carbon (POC) originating from photosynthetic production to the ocean interior and plays a key role in the sequestration of atmospheric $\mathrm{CO}_{2}$ (Sarmiento et al., 1988). The carbonate pump exports particulate inorganic carbon $\left(\mathrm{CaCO}_{3}, \mathrm{PIC}\right)$ mainly as detrital calcareous shells (Volk and Hoffert, 1985). Calcification in the mixed layer decreases total alkalinity (TA) and dissolved inorganic carbon (DIC) with a ratio 2:1 and acts as a net source of $\mathrm{CO}_{2}$ to the atmosphere over a seasonal timescale (Frankignoulle et al., 1994). If the PIC production is exported in the deep ocean below the permanent thermocline, the net impact on the atmospheric $\mathrm{CO}_{2}$ occurs at a much longer timescale corresponding to the ocean mixing time ( $\sim 1000$ years, Zeebe, 2012). This phenomenon is known as the "carbonate counter pump" effect. Additionally, it has been suggested that during the last glaciation, lower PIC:POC export ratio due to increased organic carbon export may have contributed to higher dissolution of the deep-ocean carbonate sediments, leading to a decrease in $\mathrm{pCO}_{2}$ compared to the interglacial periods (Archer and Maier-Reimer, 1994; Archer et al., 2000; Sigman and Boyle, 2000). Therefore the PIC:POC ratio of exported particles is likely to have a significant impact on the atmosphere-ocean $\mathrm{CO}_{2}$ fluxes from seasonal to geological timescales (Matsumoto et al., 2002; Sarmiento et al., 2002). More recently, in the Subantarctic Southern Ocean, the strong response of calcifying organisms to natural iron fertilization has been observed to increase the PIC:POC export ratio leading to a strong carbonate counter pump, lowering the efficiency of $\mathrm{CO}_{2}$ sequestration by the biological carbon pump (Salter et al., 2014).

Understanding how calcifying communities drive the carbonate counter pump requires a coupled description of the chemical composition and biological properties of different vectors driving $\mathrm{CaCO}_{3}$ export fluxes. Sediment trap studies provide a tractable framework to link detailed analyses of the morphological and physiological properties of exported calcareous particles (e.g. species composition, test size and test weight) with seasonal and annual geochemical budgets. In this context, the study by Salter et al. (2014) quantified a carbonate counter pump effect accounting for $6-32 \%$ of measured POC fluxes with a notable contribution from foraminifer species (mainly Globigerina bulloides and N. pachyderma) in iron-fertilized waters downstream of the Crozet Islands. Several studies have reported geochemical transitions in particle stoichiometry across the Polar Front (Trull et al., 2001; Honjo et al., 2008), highlighting the importance of regional variability for a Southern Ocean carbonate counter pump that is partly linked to the biogeography of calcareous organisms (Salter et al., 2014).

The objectives of the present study are to (1) quantify the magnitude of PIC export and the carbonate counter pump in an iron fertilized area (the Kerguelen Plateau) south of the Polar Front (Antarctic Zone, AAZ), (2) determine the relative contribution of foraminifer and coccolithophores to total PIC export in this regime, and (3) constrain the importance of species composition and test characteristics (size and size-normalized weight) for foraminifermediated PIC fluxes in iron fertilized blooms of the Southern Ocean.

\section{Materials and methods}

\subsection{Sediment trap deployment and environmental data}

As part of the KEOPS2 project (Kerguelen Ocean and Plateau compared study 2), a sediment trap (Technicap PPS3, 2.5 aspect ratio) was moored for 11 months (21 October 2011 to 7 September 2012) at 289 m over the central Kerguelen Plateau (seafloor depth $527 \mathrm{~m})$ at station A3 (50 ${ }^{\circ} 38.3 \mathrm{~S}-72^{\circ} 02.6 \mathrm{E}$, Fig. 1a,b). The carrousel comprised 12 sampling cups $(250 \mathrm{~mL})$ containing $5 \%$ formalin hypersaline solution buffered with sodium tetraborate $(\mathrm{pH}=8)$. A detailed description of the sample processing and particulate organic carbon (POC) analyses are provided in Rembauville et al. (2015b). Briefly, swimmers (zooplanktonic organisms actively entering the trap) were manually removed, samples were freeze-dried and the carbonate fraction was dissolved by the addition of acid before the organic carbon content was measured with a $\mathrm{CHN}$ analyzer.

Station A3 is characterized by a recurrent and large phytoplankton bloom induced by natural iron fertilization coming from the underlying plateau (Blain et al., 2007). Dissolved iron (dFe) is delivered to the mixed layer through two processes: winter mixing and entrainment of dFe from deeper waters and, to a less extend, vertical diapycnal diffusion of dFe in summer (Bowie et al., 2015). South of the Kerguelen Island, the polar front is permanent and non motile (Park et al., 2014) and therefore does not impact sediment trap deployment location. At the A3 station, the circulation is weak ( $<3 \mathrm{~cm} \mathrm{~s}^{-1}$ ) and primarily tidal-driven (Park et al., 2008). Physical data acquired during the sediment trap deployment suggest the record was not subject to major hydrodynamic biases (Rembauville et al., 2015b), allowing a detailed and quantitative discussion of the export fluxes.

Satellite-derived surface chlorophyll $a$ and PIC concentration (MODIS 8 days product, accessed at http://oceancolor.gsfc.nasa. gov $/ \mathrm{cms} /$ ), and sea surface temperature (NOAA OISST, weakly product, Reynolds et al., 2007) were extracted for a $100 \mathrm{~km}$ radius around the trap location. Calcite saturation state was calculated in the vicinity of the trap location with the CO2sys toolbox using climatological fields of DIC and Alkalinity (GLODAP, Key et al., 2004) and temperature, salinity, silicate and phosphate (World Ocean Atlas 2013, Garcia et al., 2013). Constants recommended for best practice were used (Dickson et al., 2007) as suggested by Orr et al. (2015).

\subsection{Calcium analyses in the bulk and fine fractions}

For bulk particulate inorganic carbon analyses, $5 \mathrm{mg}$ of freezedried material was weighed (Sartorius MC $210 \mathrm{P}$ balance) into Teflon vials for the mineralization. $1 \mathrm{~mL}$ of $65 \% \mathrm{HNO}_{3}$ was added and samples were placed in an ultrasonication bath for $20 \mathrm{~min}$. Samples were then dried overnight at $130{ }^{\circ} \mathrm{C} .0 .5 \mathrm{~mL}$ of $65 \% \mathrm{HNO}_{3}$ and $0.5 \mathrm{~mL}$ of $40 \% \mathrm{HF}$ were added and samples were ultrasonicated a second time and dried overnight. The resulting residue was dissolved in $10 \mathrm{~mL}$ of $0.1 \mathrm{~N} \mathrm{HNO}_{3}$ and calcium content analyzed by inductively coupled plasma - optical emission spectrometry (ICP-OES, Perkin-Elmer Optima 2000). The efficiency of the mineralization procedure was estimated using reference material (GBW-07314) and was > 96\%.

For the fine fractions $(20-63 \mu \mathrm{m}$ and $<20 \mu \mathrm{m})$ Ca analyses, the 

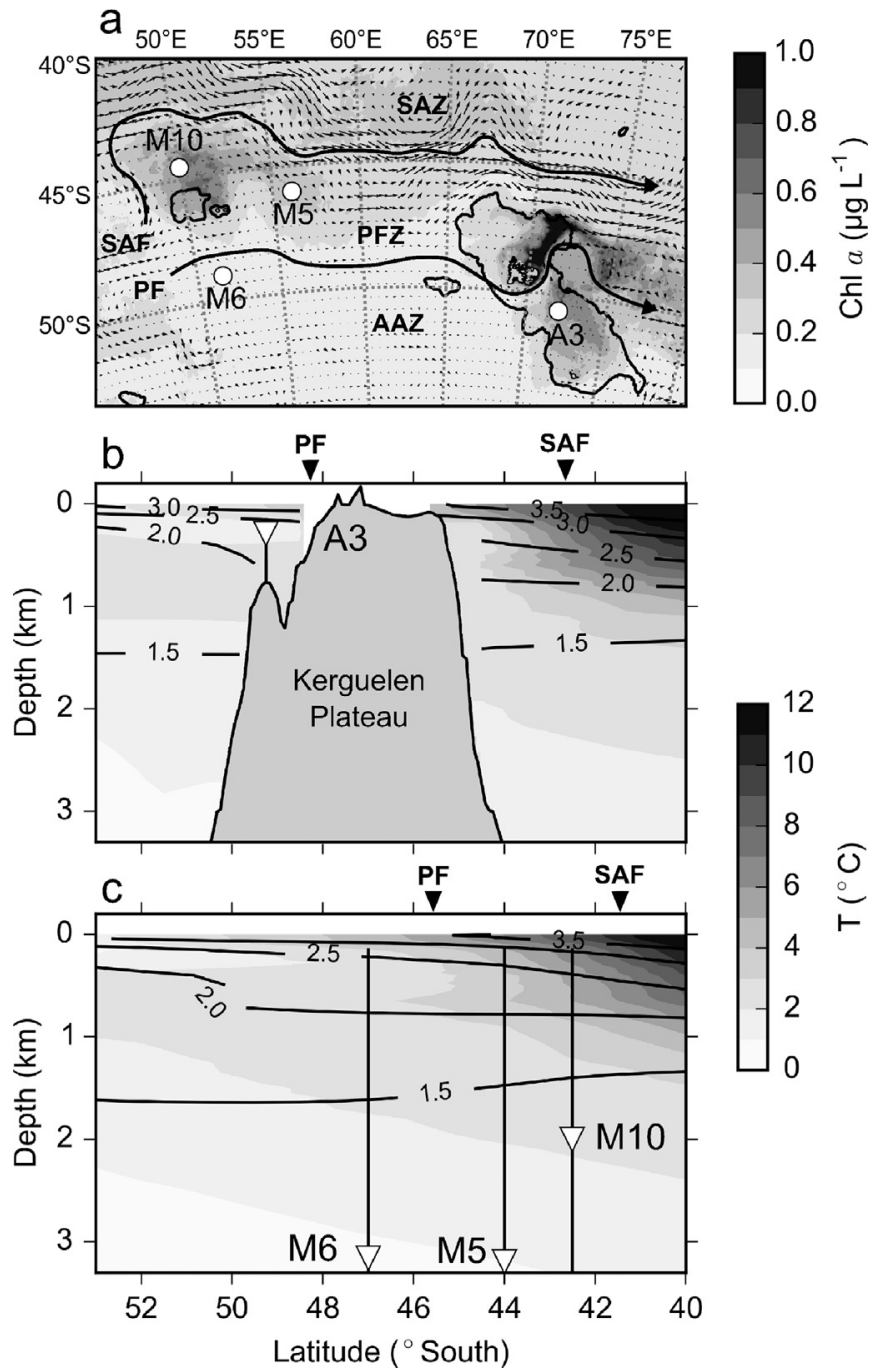

Fig. 1. (a) Map showing the locations of the sediment trap deployments in the Indian Sector of the Southern Ocean. Grey scale represents MODIS surface chlorophyll $a$ climatology. Arrows are climatological altimetry-derived surface geostrophic currents (AVISO product). Dashed lines denote the Subantarctic Front (SAF) and Polar Front (PF). SAZ: Subantarctic Zone, PFZ: Polar Frontal Zone, AAZ: Antarctic Zone. The $1000 \mathrm{~m}$ isobath is shown as a black contour line. (b) Section of temperature (World Ocean Atlas 2013, grey scale) and calcite saturation state (black isolines) along the $70^{\circ} \mathrm{E}$ meridian. (c) Same as (b) along the $55^{\circ} \mathrm{E}$ meridian.

original 1/8 split samples (Rembauville et al., 2015b) were further split into $1 / 80$ aliquots with a rotary wet-splitter (McLane WSD10) using purified water (Elix by Millipore purification system) buffered with ammonia as a rinse solution. Coccoliths in sinking particles captured in sediment trap samples may be contained in faecal pellets and/or phytoplankton aggregates. To improve the efficiency of size fraction separation by sieving it is necessary to oxidize the samples to disaggregate particles and retrieve the entire carbonate fine fraction (Bairbakhish et al., 1999; Broerse et al., 2000; Ziveri et al., 2000; Stoll et al., 2007). The 1/80 aliquots were placed in a $50 \mathrm{~mL}$ centrifugation tube for the oxidation steps using a method adapted from Bairbakhish et al. (1999). Samples were centrifuged (5000 rpm, $5 \mathrm{~min}$ ) and the supernatant withdrawn. Subsequently, $3 \mathrm{~mL}$ of Elix water buffered with ammonia, $3 \mathrm{~mL}$ of $5 \% \mathrm{NaClO}$ and $1.5 \mathrm{~mL}$ of $30 \% \mathrm{H}_{2} \mathrm{O}_{2}$ were added and the samples were ultrasonicated for $10 \mathrm{~s}$. Every $10 \mathrm{~min}, 2 \mathrm{~mL}$ of $\mathrm{NaClO}$ were added and samples were ultrasonicated for $10 \mathrm{~s}$. This cycle was repeated for one hour. The oxidized aliquot was wet-sieved over a $63 \mu \mathrm{m}$ and a $20 \mu \mathrm{m}$ mesh, and the two resulting size fractions $(20-63 \mu \mathrm{m}$ and $<20 \mu \mathrm{m})$ were filtered on polycarbonate membranes ( $0.4 \mu \mathrm{m}$ pore size, $47 \mathrm{~mm}$ diameter). Filters were dried at $40{ }^{\circ} \mathrm{C}$ and the residue was leached in $10 \mathrm{~mL} 1 \% \mathrm{HNO}_{3}$, ultrasonicated for $10 \mathrm{~min}$ and left $12 \mathrm{~h}$ at room temperature before the $\mathrm{Ca}$ analysis. Ca concentration was analyzed by inductively coupled plasma-atomic emission spectrometry (ICP-AES, Perkin Elmer, Optima 4300DV). Overall accuracy amounted to better than $2 \%$ based on replicate analysis.

For the qualitative analyses of the coccolithophore species composition, samples were prepared in a similar way as for the fine fraction $\mathrm{Ca}$ analysis (oxidation and sieving) and then filtered on cellulose acetate membranes (Millipore, $0.45 \mu \mathrm{m}$ pore size, $47 \mathrm{~mm}$ diameter). Filters were dried at $40{ }^{\circ} \mathrm{C}$ and observed under a polarized microscope at 1200 magnification.

\subsection{Foraminifer carbonate flux estimation}

Foraminifer quantification, morphometric measurements and weighing was performed following the methods outlined in Salter et al. (2014). One $1 / 8$ aliquot was sieved on a $63 \mu \mathrm{m}$ mesh with tap water and the $>63 \mu \mathrm{m}$ fraction was dried overnight $\left(40{ }^{\circ} \mathrm{C}\right)$. Dried particles were homogeneously placed on a glass tray. Images of the entire $1 / 8$ sample were acquired with a fully automated incident light monocular microscope (Leica Z16 APO), and a motorized xystage with a Lstep-PCI controller (Märzhäuser). High-resolution images $\left(1.4 \mu \mathrm{m}^{-2}\right.$ pixel $\left.^{-1}\right)$ were taken with a color camera (SIS CC12). Particle size (minimum test diameter, $d_{\text {min }}$ ) was automatically analyzed using analySIS FIVE software (SIS/Olympus with a MAS software add-in). Foraminifer species were manually counted and classified into morpho-species following the taxonomic concept of Hemleben et al. (1989). Eight species of planktic foraminifer were identified: Neogloboquadrina pachyderma (left coiling), Neogloboquadrina incompta (right coiling), Turborotalita quinqueloba, Globigerinita uvula, Globigerinita glutinata, Globorotalia inflata, Globigerinoides ruber (sensu stricto) and Trilobatus sacculifer (normal type). Only one empty shell of pteropod (Limacina helicina) was found in the samples and therefore pteropod's contribution to the passive carbonate flux was considered negligible. However, numerous pteropods were found as swimmers (distinguished by well preserved organic material) actively entering the trap in late summer (Rembauville et al., 2015b). Those shells were withdrawn from the samples as they were considered not to contribute to the passive flux. To determine size-weight relationships, individuals of $N$. pachyderma $(\mathrm{n}=23), N$. incompta $(n=10)$, T. quinqueloba $(n=60)$ were manually picked from samples representative of different flux conditions (spring, summer and winter). Individuals were placed in aluminium cups and weighed (Mettler Toledo XP2U, $0.1 \mu$ g precision). Samples were acclimatized in the weighing room for at least $12 \mathrm{~h}$ before the analysis. Once the test weight was determined, the minimal diameter $\left(d_{\text {min }}\right)$ of each individual was measured with the procedure described above. Size-weight relationships $\left(\mathrm{W}=\mathrm{a} \times \mathrm{d}_{\mathrm{min}}^{\mathrm{b}}\right)$ were constructed by fitting linear regressions to log-transformed data (Movellan et al., 2012). A species-specific relationship was developed for $N$. pachyderma, $N$. incompta and T. quinqueloba. For the other species, an average size-weight relationship was calculated by pooling the entire foraminifer dataset $(n=93)$. Parameters of the size-weight relationships are given in Table 1. Foraminifer carbonate flux was then calculated using the abundance and size from the whole dataset and species or group-specific size-weight relationships. We refer to the sum of foraminifer and fine fractions (20-63 $\mu \mathrm{m}$ and $<20 \mu \mathrm{m}$ ) PIC as "calculated PIC".

\subsection{Test size and size normalized weight comparison with assem- blages from Crozet}

Discrete measurements of the test size and weight of 
Table 1

Parameters of the size-weight relationship (W $\left.(\mu \mathrm{g})=\mathrm{a} \times \mathrm{d}_{\min }(\mu \mathrm{m})^{\mathrm{b}}\right)$ for the different foraminifer groups OR species considered. All the regressions are highly significant $(p<0.01)$.

\begin{tabular}{llllll}
\hline Species & $\begin{array}{l}\mathrm{d}_{\text {min }} \text { range } \\
(\mu \mathrm{m})\end{array}$ & $\begin{array}{l}\text { W range } \\
(\mu \mathrm{g})\end{array}$ & $\mathrm{a}$ & $\mathrm{b}$ & $\mathrm{R}^{2}$ \\
\hline $\begin{array}{l}\text { N. pachyderma } \\
(\mathrm{n}=23)\end{array}$ & $102-300$ & $0.3-5.5$ & $5.26 \times 10^{-7}$ & 2.90 & 0.71 \\
$N$. incompta $(\mathrm{n}=10)$ & $128-230$ & $0.9-3.0$ & $3.98 \times 10^{-4}$ & 1.61 & 0.77 \\
T. quinqueloba $(\mathrm{n}=60)$ & $132-340$ & $0.3-4.9$ & $3.54 \times 10^{-9}$ & 3.85 & 0.71 \\
Global $(\mathrm{n}=93)$ & $102-340$ & $0.3-5.5$ & $1.25 \times 10^{-7}$ & 3.16 & 0.67 \\
\hline
\end{tabular}

foraminifer individuals facilitate the calculation of size-normalized weight (SNW), a commonly used descriptor of test density/thickness (Bijma et al., 1999; Beer et al., 2010a; Marshall et al., 2013). The SNW was calculated for each individual by dividing the weight by the minimum test diameter (SNW $\left(\mu \mathrm{g} \mu \mathrm{m}^{-1}\right)=\mathrm{W} / \mathrm{d}_{\mathrm{min}}$ ). Given the good relationship between area and minimum diameter, this method is considered as an appropriate mean to characterize the test density (Beer et al., 2010b). We compared the Kerguelen dataset (station A3, AAZ) with previously published size and weight data using the same methodology from the Crozet Islands (Salter et al., 2014). Stations M10 and M5 are located in the PFZ (Pollard et al., 2007). Altimetry data suggest station M6 might be seasonally influenced by a weakly marked Polar Front (Park et al., 1993; Pollard et al., 2007), but the presence of a temperature minimum layer $\left(1.6{ }^{\circ} \mathrm{C}\right.$ at $\left.200 \mathrm{~m}\right)$ strongly supports its belonging to the $\mathrm{AAZ}$ (Pollard et al., 2002; Planquette et al., 2007; Salter et al., 2014). Statistical differences in minimum diameter $\left(\mathrm{d}_{\min }\right)$ and size-normalized weight (SNW) between the four study sites were tested for three species independently (N. pachyderma, T. quinqueloba, G. bulloides) using a non-parametric Kruskall-Wallis test. If the four sites constituted significantly different groups, a post-hoc Tuckey test was performed to identify which sites were significantly different from the others. If the four sites constituted a significantly homogeneous group, the data from the four sites were pooled for each species and differences between the three species were tested using a Kruskall-Wallis test followed by a Tuckey post-hoc test. All tests were performed at a significance level of $5 \%$.

\section{Results}

\subsection{Seasonality of POC and bulk PIC fluxes}

Surface chlorophyll a concentration displayed two peaks (Fig. 2a). The major peak $\left(2.5 \mu \mathrm{g} \mathrm{L}^{-1}\right)$ occurred during spring at the onset of thermal stratification (November 2011) and a second moderate peak $\left(1 \mu \mathrm{g} \mathrm{L}^{-1}\right)$ in summer (January 2012). POC fluxes were characterized by two short ( $<15$ days) and intense $\left(\sim 1.5 \mathrm{mmol} \mathrm{m}^{-2} \mathrm{~d}^{-1}\right)$ export events lagging the chlorophyll $a$ peaks by one month. These two POC export events comprised primarily Thalassiosira antarctica and Chaetoceros Hyalochaete resting spores (Rembauville et al., 2015a).

The satellite-derived mixed layer PIC concentration displayed a clear seasonal pattern (Fig. 2a) with moderate values in spring $\left(0.4 \mu \mathrm{mol} \mathrm{L}^{-1}\right.$ in October/November 2011) and a strong increase in summer to reach nearly $1 \mu \mathrm{mol} \mathrm{L}^{-1}$ in end January 2012. The PIC concentration decreased gradually after this summer peak to reach low values of $0.2 \mu \mathrm{mol} \mathrm{L}^{-1}$ in winter 2012. Total bulk PIC fluxes displayed a similar seasonality as the surface satellite-derived PIC concentration (Fig. 2b). A moderate peak of $33 \mu \mathrm{mol} \mathrm{m}^{-2} \mathrm{~d}^{-1}$ in the first cup (21 October to 4 November 2011) was followed by very low fluxes for the remainder of spring $\left(<10 \mu \mathrm{mol} \mathrm{m}{ }^{-2} \mathrm{~d}^{-1}\right)$. PIC fluxes gradually increased in the summer to $30 \mu \mathrm{mol} \mathrm{m}^{-2} \mathrm{~d}^{-1}$
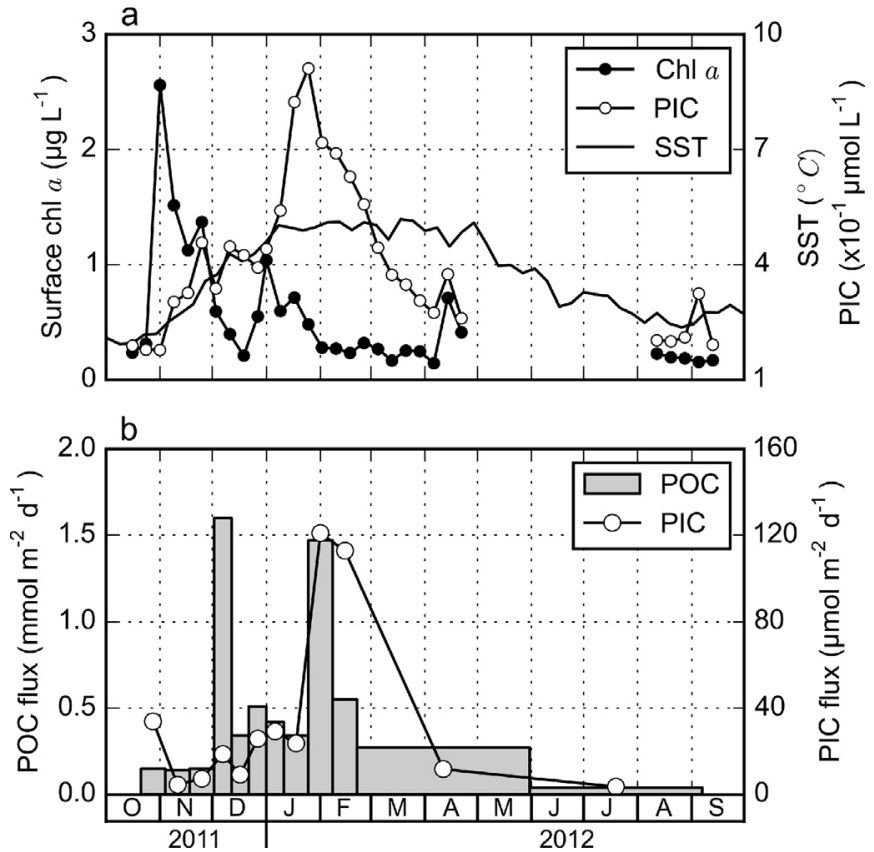

Fig. 2. (a) Satellite-derived surface chlorophyll $a$ (black dots), particulate inorganic carbon (PIC, white dots) and sea surface temperature (SST, black line) averaged in a $100 \mathrm{~km}$ radius around the trap located at the A3 station. (b) Particulate organic carbon (POC) and bulk particulate inorganic carbon (PIC) fluxes from the $\mathrm{A} 3$ sediment trap.

before a clear maximum in late summer (110-120 $\left.\mu \mathrm{mol} \mathrm{m}^{-2} \mathrm{~d}^{-1}\right)$ that persisted for one month (25 January to 22 February 2015). Autumn and winter fluxes were very low $\left(<12 \mu \mathrm{mol} \mathrm{m}^{-2} \mathrm{~d}^{-1}\right)$. Assuming negligible PIC flux out of the collecting period (corresponding to the months of September and October characterized by low chlorophyll $a$ concentration), the annual PIC export was low (6.6 mmol m-2 $\mathrm{yr}^{-1}$ ). The annually-integrated PIC:POC molar ratio was equal to 0.07 .

\subsection{Seasonal dynamics of foraminifer and coccolith export fluxes}

The seasonality of total foraminifer test flux closely followed chlorophyll a dynamics (Fig. 3a). A major peak of 800 indiv. $\mathrm{m}^{-2} \mathrm{~d}^{-1}$ was observed in spring. In December, when surface chlorophyll $a$ concentrations were low, the total foraminifer flux was very low (15 indiv. $\mathrm{m}^{-2} \mathrm{~d}^{-1}$ ). During the second surface chlorophyll $a$ increase (January to mid-February), the total foraminifer flux increased again to reach values of 450-550 indiv. $\mathrm{m}^{-2} \mathrm{~d}^{-1}$. Foraminifer flux was very low in autumn (30 indiv. $\mathrm{m}^{-2} \mathrm{~d}^{-1}$ ) and negligible in winter. There was no major seasonal change in the foraminifer assemblage throughout the year. At an annual scale, 4 species dominated $(>95 \%)$ the foraminifer flux. The community assemblage was dominated by $T$. quinqueloba (31.8\%), closely followed by $N$. pachyderma (30.8\%) with lower contributions of $N$. incompta (18\%) and G. uvula (15.3\%) (Table 2).

Total and fine fractions $(20-63 \mu \mathrm{m}$ and $<20 \mu \mathrm{m})$ PIC fluxes are presented in Fig. 3c. The 20-63 $\mu \mathrm{m}$ fine fraction displayed very low fluxes $\left(<15 \mu \mathrm{mol} \mathrm{m}{ }^{-2} \mathrm{~d}^{-1}\right.$ ) throughout the year with maximum in February 2012. The fine fraction $<20 \mu \mathrm{m}$ fluxes followed a similar seasonal pattern as total PIC fluxes. Spring and summer (October to mid-January) were characterized by low fluxes with values $<25 \mu \mathrm{mol} \mathrm{m}^{-2} \mathrm{~d}^{-1}$ and peaked to the highest values $\sim 100 \mu \mathrm{mol} \mathrm{m}^{-2} \mathrm{~d}^{-1}$ in late summer (February). In autumn and winter, the PIC fine fraction $<20 \mu \mathrm{m}$ fluxes were $<15 \mu$ $\mathrm{mol} \mathrm{m} \mathrm{m}^{-2} \mathrm{~d}^{-1}$ 

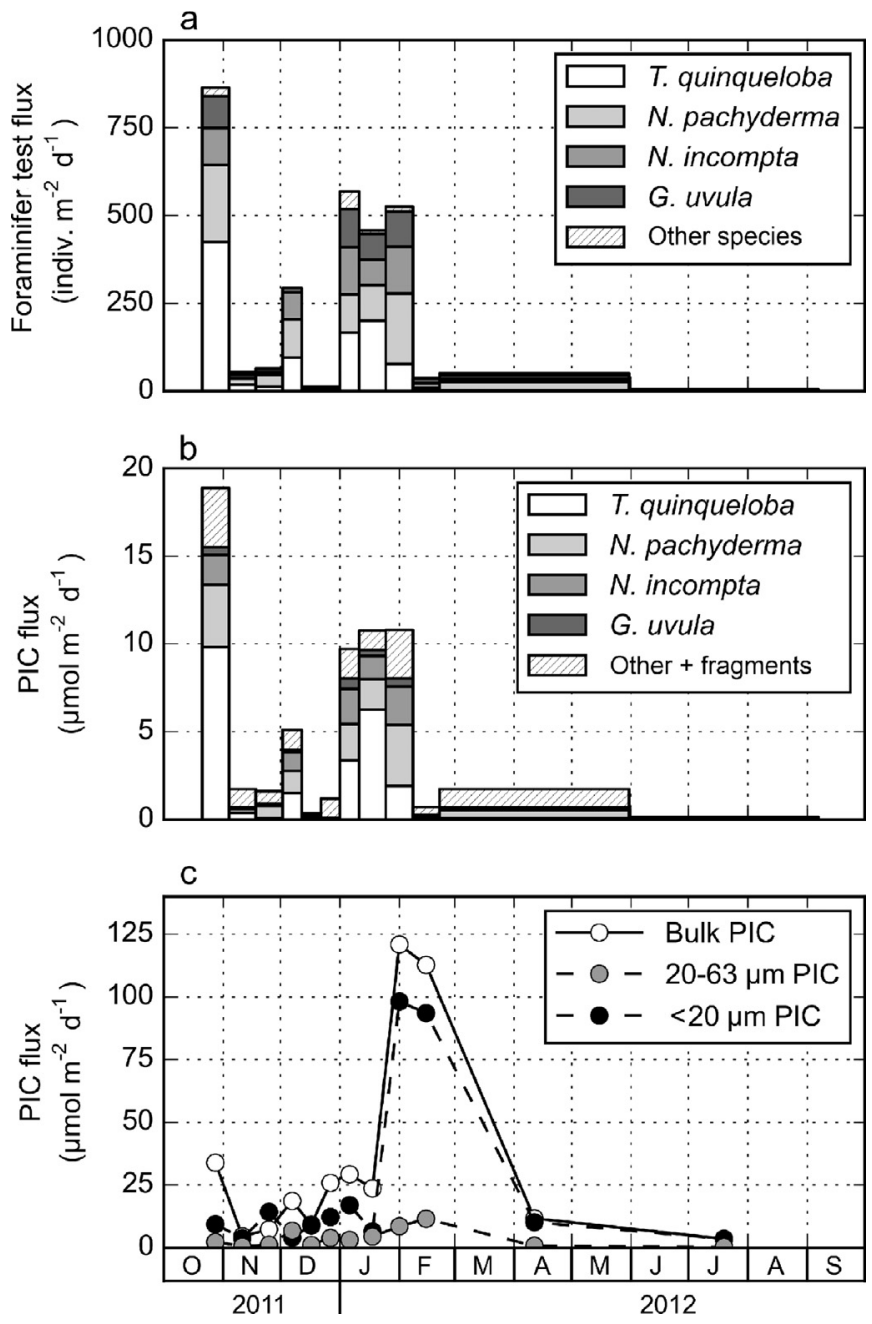

Fig. 3. (a) Numerical test fluxes of planktic foraminifers recorded by the sediment trap at the A3 station. (b) Corresponding foraminifer PIC fluxes. (c) Fine fractions PIC fluxes (20-63 $\mu \mathrm{m}$ - grey dots, $<20 \mu \mathrm{m}$-black dots), and bulk PIC flux (circles).

Table 2

Relative contribution of foraminifer species to the annual numerical export and annual foraminifer PIC. Relative contribution of foraminifers and fine fractions $(<63 \mu \mathrm{m})$ to the calculated annual PIC export.

\begin{tabular}{llll}
\hline Species/group & $\begin{array}{l}\text { Numerical for- } \\
\text { aminifer flux }(\%)\end{array}$ & $\begin{array}{l}\text { Foraminifer PIC } \\
(\%)\end{array}$ & $\begin{array}{l}\text { Calculated PIC } \\
(\%)\end{array}$ \\
\hline N. pachyderma & 30.8 & 22.6 & 3.3 \\
N. incompta & 18.0 & 11.9 & 1.8 \\
T. quinqueloba & 31.8 & 32.8 & 4.9 \\
G. uvula & 15.3 & 3.4 & 0.5 \\
Other foraminifer & 4.1 & 10.3 & 1.4 \\
$\quad$ species & & 19.0 & 2.8 \\
Foraminifer & & & 14.8 \\
$\quad$ fragments & & & 85.2 \\
Total foraminifers & & & 70 \\
$<63 \mu \mathrm{m}$ & & 75.2 \\
$20-63 \mu \mathrm{m}$ & & & \\
$<20 \mu \mathrm{m}$ & & \\
\hline
\end{tabular}

\subsection{Relative contribution of foraminifers and coccoliths to carbonate export}

The individual size-weight relationships were considered sufficiently reliable to calculate the contribution of each foraminifer species to the PIC export (all fits were highly significant, $R^{2}>0.66$, Table 1). The total foraminifer-mediated PIC export showed a seasonality comparable to the surface chlorophyll $a$ with a strong peak in early spring $\left(18 \mu \mathrm{mol} \mathrm{m}^{-2} \mathrm{~d}^{-1}\right.$ in October 2011) and a secondary increase in late summer $\left(11 \mu \mathrm{mol} \mathrm{m}{ }^{-2} \mathrm{~d}^{-1}\right.$ in Januray 2011). Fluxes were much lower the remainder of the year $(<5 \mu$ mol m $\mathrm{m}^{-2} \mathrm{~d}^{-1}$ ).The relative contribution of each foraminifer species/group to the total foraminifer PIC and the calculated PIC annual flux is reported in Table 2. The relative contribution of the major foraminifer species to the total foraminifer PIC fluxes was comparable to their contribution to numerical fluxes, and a notable fraction (19\%) of foraminifer PIC was exported as unclassified test fragments. T. quinqueloba displayed the highest contribution to the calculated PIC (4.9\%), followed by N. pachyderma (3.3\%) and $N$. incompta (1.8\%). The contribution of G. uvula was very low (0.5\%). Microscopic observations of the fine size fractions after the organic oxidation step revealed the absence of juvenile foraminifers and calcareous dinophytes in the 20-63 $\mu \mathrm{m}$ size fraction and the presence of coccoliths aggregated to diatom frustules and unidentified $\mathrm{CaCO}_{3}$ fragments. Therefore, the $<20 \mu \mathrm{m}$ fine fraction represents a slight underestimation of coccolith calcite fluxes (Ziveri et al., 2007). The total contribution of foraminifer tests to the annual calculated PIC export was $14.8 \%$. Conversely, the contribution of the coccolith fine fractions $(<20 \mu \mathrm{m}$ and $20-63 \mu \mathrm{m})$ to the annual calculated PIC flux was high (85.2\%), primarily due to their major contribution in the late summer export peak.

The relationship between the bulk and calculated PIC flux is presented in Fig. 4. Data points are close to the 1:1 relationship. A highly significant linear correlation (Pearson, $\mathrm{n}=12, p<0.01$ ) existed between the bulk and calculated PIC. Regression suggested a slope close to $1\left(0.94, \mathrm{R}^{2}=0.99\right)$ and the annual calculated PIC export $\left(6.5 \mathrm{mmol} \mathrm{m}^{-2}\right)$ was very close to the annual bulk PIC flux measured $\left(6.6 \mathrm{mmol} \mathrm{m}^{-2}\right)$. These statistics ensure the analytical method was robust and the partitioning of PIC fluxes among the quantified biological vectors accounted for the majority of total PIC measured in the samples.

\subsection{Foraminifer test size and SNW comparison with Crozet}

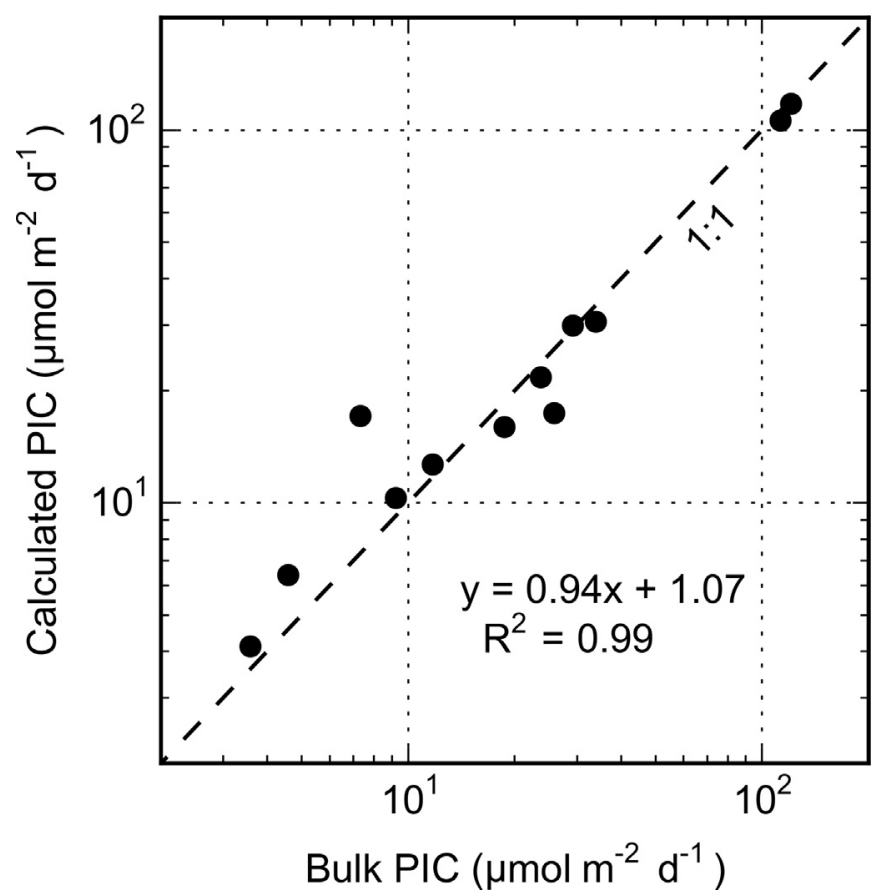

Fig. 4. Relationship between the measured bulk PIC flux and the calculated PIC flux (sum of the foraminifer, the $20-63 \mu \mathrm{m}$ and the $<20 \mu \mathrm{m}$ fine fractions PIC fluxes). Dashed line denotes the 1:1 relationship. The equation of the regression performed on the raw data is given. 



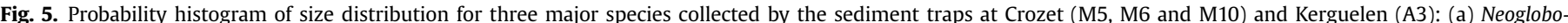

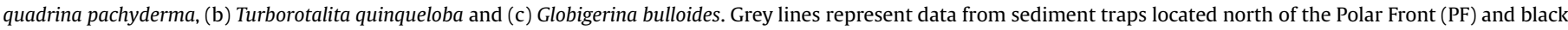
lines south of the PF.

\section{assemblages}

Probability histograms of size distribution at each site for $N$. pachyderma, T. quinqueloba and $G$. bulloides are presented in Figs. 5a, b and c, respectively. All the density functions displayed quasi-unimodal distributions. For $N$. pachyderma, $\mathrm{d}_{\text {min }}$ was significantly higher in the AAZ (M6 and A3 sites, $195 \pm 39 \mu \mathrm{m}$, mean \pm standard deviation) than the PFZ (M5 and M10 sites, $151 \pm 30 \mu \mathrm{m})$. For $T$. quinqueloba, $\mathrm{d}_{\min }$ was significantly higher at A3 $(206 \pm 51 \mu \mathrm{m})$ than at the three other sites (M5, M10 and M6, $167 \pm 29 \mu \mathrm{m}$ ) that constituted a significantly homogeneous group. Only $5 \mathrm{~g}$. bulloides were observed at A3 and therefore were not taken into account in the analysis. For $G$. bulloides, $\mathrm{d}_{\min }$ was significantly homogeneous at the three Crozet sites (M5, M10 and M6, $244 \pm 65 \mu \mathrm{m})$.

Boxplots of SNW are presented for the three species in Fig. 6. For each species, there was no significant difference in SNW among sites. Therefore, the data from all the sites were pooled by species. Each species SNW constituted a significantly homogeneous group different from the two others. G. bulloides SNW $\left(31 \pm 14 \times 10^{-3} \mu \mathrm{g} \mu \mathrm{m}^{-1}\right.$, mean \pm standard deviation) was significantly higher than $N$. pachyderma SNW $\left(18 \pm 11 \times 10^{-3} \mu\right.$ $\mathrm{g} \mu \mathrm{m}^{-1}$ ) that was also significantly higher than T. quinqueloba SNW $\left(10 \pm 4 \times 10^{-3} \mu \mathrm{g} \mu \mathrm{m}^{-1}\right)$ (Fig. 6).

\section{Discussion}

\subsection{Foraminifer test flux amplitude and seasonality}

We observed moderate planktic foraminifer test fluxes of 5001000 indiv. $\mathrm{m}^{-2} \mathrm{~d}^{-1}$ despite high primary production levels in this naturally iron-fertilized area. The low test fluxes we report over the central Kerguelen Plateau, and the dominance of $N$. pachyderma and T. quinqueloba are consistent with the general decrease in flux from the SAZ to the AAZ that goes with a switch from a mixture of subpolar and polar water species to a dominance of the two aforementioned species. Donner and Wefer (1994) reported very low fluxes $\left(\sim 50\right.$ indiv. $\left.\mathrm{m}^{-2} \mathrm{~d}^{-1}\right)$ in the Northern Weddell Sea and Bransfield Strait (AAZ) whereas fluxes where much higher at the Maud Rise $\left(\sim 1 \times 10^{3}\right.$ indiv. $\left.\mathrm{m}^{-2} \mathrm{~d}^{-1}\right)$ where $N$. pachyderma dominated the community assemblage, followed by T. quinqueloba. King and Howard (2003) reported foraminifer export fluxes south of Tasmania with highest numerical fluxes of $\sim 1 \times 10^{4}$ indiv. $\mathrm{m}^{-2} \mathrm{~d}^{-1}$ in the SAZ very close to the SAF and lower values $\left(4 \times 10^{3}\right.$ indiv. $\mathrm{m}^{-2} \mathrm{~d}^{-1}$ ) in the PFZ. The transition from SAZ to PFZ was associated with a switch from temperate species to a dominance of N. pachyderma and T. quinqueloba. South of New Zealand, Northcote and Neil (2005) described fluxes of $5 \times 10^{3}$ indiv. $\mathrm{m}^{-2} \mathrm{~d}^{-1}$ with a major contribution of G. inflata in the SAZ. In the PFZ North of the Crozet Islands, foraminifer numerical export fluxes were
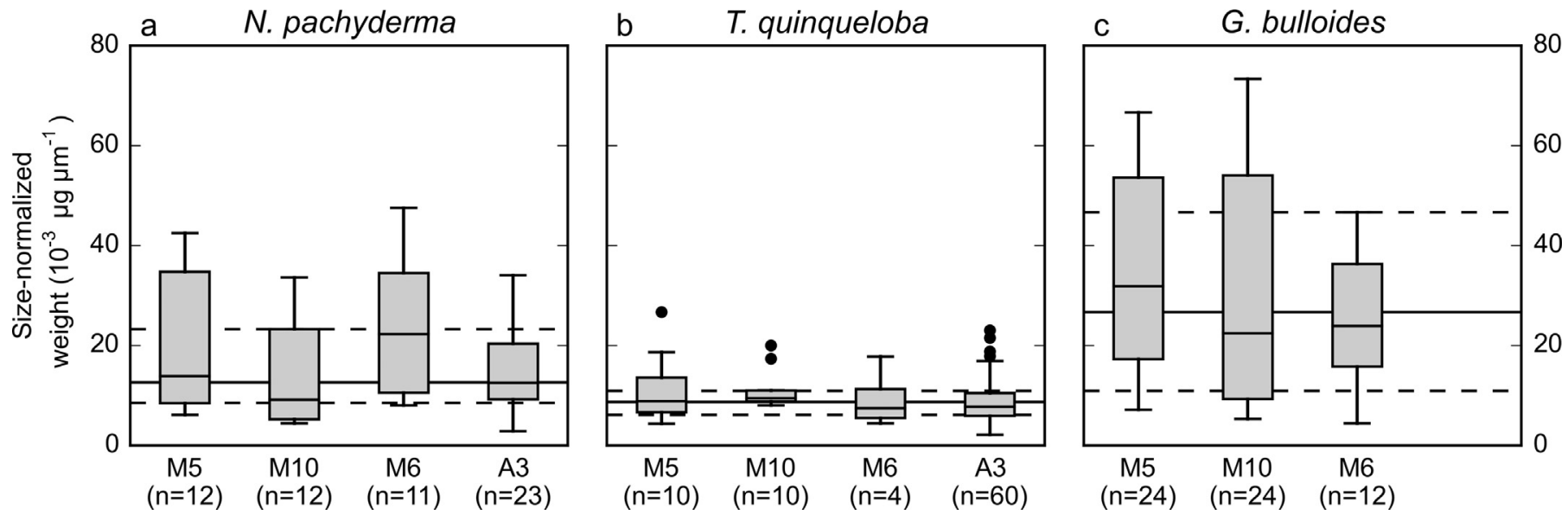

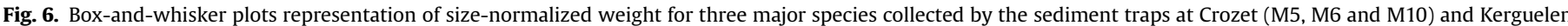

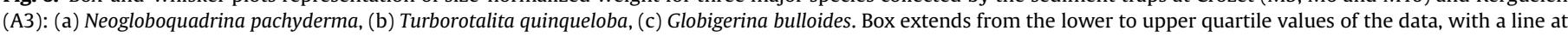


upper quartile (dashed lines) calculated by grouping all samples for a given species. 
$\sim 1 \times 10^{4}$ indiv. $\mathrm{m}^{-2} \mathrm{~d}^{-1}$ and mostly represented by $N$. pachyderma with a notable contribution of the larger temperate species G. bulloides and G. inflata (Salter et al., 2014).

The seasonal dynamics of foraminifer test export flux at station A3 was characterized by two peaks in spring and summer closely related with surface chlorophyll a concentration, but were not particularly associated with SST dynamics. Jonkers and Kučera (2015) have analyzed the phenology of foraminifer export fluxes at global scale and demonstrated that a group composed of temperate and cold water species (comprising $N$. pachyderma, N. incompta and $T$. quinqueloba) displayed two export peaks in spring and summer. Our results are highly consistent with this general scheme and support the close link between primary production (assessed from surface chlorophyll $a$ ) and foraminifer production (Hemleben et al., 1989; Klaas, 2001; Schiebel et al., 2001; Kuroyanagi and Kawahata, 2004; Lombard et al., 2011) and subsequent export (Schiebel, 2002). At Crozet (M5 and M10 sites in PFZ) foraminifer test export occurred in one continuous event in summer from January to March (Salter et al., 2014) when SST was generally highest $\left(>8^{\circ} \mathrm{C}\right)$ and chlorophyll $a$ concentration was low $\left(0.5 \mu \mathrm{g} \mathrm{L}^{-1}\right.$, Salter et al., 2012). This strongly contrasts with the close link we observe between the chlorophyll $a$ concentration and the foraminifer test export at A3. However, the comparison of flux seasonality must be treated with caution because of the different sediment trap deployment depths ( $289 \mathrm{~m}$ at A3 versus $>2500 \mathrm{~m}$ for the M5 and M10 sites), increasing water depth might dampen seasonal particle flux signal. Our results from a shallow sediment trap at A3 suggest that food availability might be the major controlling factor for low temperature communities of the AAZ.

\subsection{Foraminifer test size and SNW distribution}

The calculation of the calcite saturation state is strongly dependent on the input variables of DIC and Alkalinity (a 1\% change in one of these variables can drive a $10 \%$ change in saturations state, Orr et al., 2015). Given this uncertainty, the climatological field suggests that all of the sediment trap deployments around Crozet and Kerguelen were located in waters oversaturated with respect to $\mathrm{CO}_{3}{ }^{2-}$ with a calcite saturation state $>1$ (Fig. 1b,c). Therefore it is unlikely that seawater carbonate chemistry has strongly affected test weight and size through dissolution during particle sinking. However, test dissolution would lead to an underestimation of the weight in the sediment trap material and therefore the SNW should be considered as a lower estimate compared to living individuals.

The compilation of the large dataset generated with the automated microscope from Crozet and Kerguelen samples revealed that location relative to the Polar Front had a significant impact on the size of $N$. pachyderma with smaller individuals in the PFZ (Fig. 5). This pattern was not evident for T. quinqueloba and $G$. bulloides. When food is not limiting, temperature is presumed a fundamental factor influencing foraminifer growth rate at the species level (Lombard et al., 2009). An explanation of the Bergmann's rule (larger individuals in colder environments) in plankton is that lower growth rate due to lower temperature leads to larger individuals at sexual maturity (von Bertalanffy, 1960; Atkinson, 1994). Under this hypothesis, colder SST south of the Polar Front might explain larger individuals of $N$. pachyderma at M6 and A3 sites. However the fact that Crozet communities of $T$ quinqueloba and G. bulloides have a significantly homogeneous size in the PFZ and AAZ suggests that temperature is not the only factor at play and that population dynamics (Schiebel et al., 1997) and the availability of prey (Schmidt et al., 2004) as well as genetic diversity within a given morphospecies (Weiner et al., 2015) might also constrain planktonic foraminifer size.

SNW was originally considered as a proxy for $\left[\mathrm{CO}_{3}{ }^{2-}\right]$
(Lohmann, 1995; Bijma et al., 1999; Broecker and Clark, 2001; Barker and Elderfield, 2002; Bijma et al., 2002). Additionally, the comparison of foraminifer tests from modern sediment traps samples and Holocene sediments demonstrated the impact of ocean acidification and the lowering of $\left[\mathrm{CO}_{3}{ }^{2-}\right]$ on the reduction of the test weight at high southern latitudes (Moy et al., 2009). However, there is a growing number of observations suggesting that the relationship between the SNW and the $\left[\mathrm{CO}_{3}{ }^{2-}\right]$ is not homogeneous among foraminifer species (Beer et al., 2010a; Meilland, 2015), and the relationship is more robust for certain species than for others (Marshall et al., 2013). Our results show that for a given species, SNW is not statistically different regarding the hydrography but that SNW varies significantly between the dominant species $N$. pachyderma, T. quinqueloba and G. bulloides. This suggests that ecological conditions other than the carbon chemistry of ambient seawater at long (Weinkauf et al., 2013) and short time scale (de Villiers, 2004; Marshall et al., 2013), and species physiological characteristics and metabolism might be responsible for the three-fold SNW increase between T. quinqueloba and $G$. bulloides. This has potentially important implications for the carbon pumps because it implies that planktic foraminifer community composition together with the magnitude of the numerical flux (number of individuals) plays a role in the foraminifer-mediated PIC flux.

\subsection{Seasonality and magnitude of the coccolith fine fraction export}

The sediment trap record represents the first annual record of coccolith calcite export south of the Polar Front. Over the central Kerguelen Plateau, we observe a clear decoupling between the two chlorophyll $a$ peaks (November and January) and the coccolith fine fraction $(<20 \mu \mathrm{m})$ export peak (February). The algorithm used to calculate PIC concentration based on satellite remote sensing reflectance is associated with a root mean square error (RMSE) of $1.2 \mu \mathrm{mol} \mathrm{L}^{-1}$ (Balch et al., 2005). The maximum satellite-derived PIC concentration we report is $\sim 1 \mu \mathrm{mol} \mathrm{L}^{-1}$ which is lower than the RMSE. Additionally, the sunlight penetration depth constraining satellite data is $<20 \mathrm{~m}$ in such a productive area (Gordon and McCluney, 1975), preventing the detection of subsurface features. For this reason, we only consider the satellite-derived PIC as qualitative date product. The uncertainty on satellite-derived PIC concentration, the shallow sediment trap depth $(289 \mathrm{~m})$ and the sampling temporal resolution (15 days) prevent a robust calculation of coccolith sinking speed or turnover time. However, the satellite-derived PIC concentration displays a clear seasonal signal tightly coupled to the coccolith fine fraction export. This result suggests that the algorithm used to derive coccolithophore presence from satellite data (Gordon et al., 2001; Balch et al., 2005) is sensitive, if not quantitative, over the central Kerguelen Plateau.

Historical observations suggest a diatom to coccolithophore succession from spring to summer in various locations of the global ocean (Margalef, 1978; Holligan et al., 1983; Lochte et al., 1993; Ziveri et al., 1995; Thunell et al., 1996; Ziveri and Thunell, 2000; Schiebel et al., 2011). Using satellite hyperspectral measurements and the PhytoDOAS method, Sadeghi et al. (2012) built a climatology of coccolithophore biomass in the Southern Atlantic. They reported a recurrent coccolithophore bloom in February/ March, in good agreement with our measurement of maximum fine fraction $(<20 \mu \mathrm{m})$ export flux in February. Sadeghi et al. (2012) highlighted the importance of SST maxima for the origination of a coccolithophore bloom in the high latitude ocean. Similarly, we report the highest coccolith calcite export flux during the period of highest SST $\left(\sim 5^{\circ} \mathrm{C}\right)$, in agreement with the hypothesis of a temperature control on the coccolithophore bloom. More recently, Hopkins et al. (2015) used satellite-derived PIC as a proxy of coccolithophore biomass and concluded to a co- 
occurrence of chlorophyll $a$ and coccolithophore peaks in the Southern Ocean. The results at large spatial and temporal scales differ somewhat from the uncoupling we observe at our specific location. Such differences may be attributed to inter-annual variability in the seasonality of chlorophyll $a$ concentrations and/ or the timing of coccolithophore production.

The qualitative microscopic observation of the $<20 \mu \mathrm{m}$ and 20-63 $\mu \mathrm{m}$ fractions indicate that Emiliania huxleyi represents $>95 \%$ of the coccolithophores assemblage with a minor contribution of Helicosphaera carteri. This finding is consistent with previous observations of a strict dominance of E. huxleyi with low abundances south of the PF (Saavedra-Pellitero et al., 2014; Winter et al., 2014). E. huxleyi is reported to bloom in waters with generally low silicic acid concentration resulting by its consumption by diatoms (Holligan et al., 1983; Townsend et al., 1994; Tyrrell and Merico, 2004). Additionally, this species has been shown to be tolerant to low iron concentration (Brand et al., 1983; Sunda and Huntsman, 1995; Muggli and Harrison, 1997; Findlay and Giraudeau, 2000; Holligan et al., 2010). In January, the silicic acid concentration at the station $\mathrm{A} 3$ reaches $<2 \mu \mathrm{mol} \mathrm{L}^{-1}$ (Mosseri et al., 2008) and iron concentration is $\sim 0.1 \mathrm{nmol} \mathrm{L}^{-1}$ (Blain et al., 2008). Moreover, the high nitrate, phosphate and ammonium concentrations (Mosseri et al., 2008) and the highest SST in late summer might be favorable conditions for a $E$. huxleyi bloom. Nevertheless, despite the summer stratification, the SST of $5{ }^{\circ} \mathrm{C}$ is still in the lower end of the thermal niche of E. huxleyi $\left(1-31^{\circ} \mathrm{C}\right.$, McIntyre et al., 1970). This temperature is likely to result in relatively low growth rate (Fisher and Honjo, 1989; Fielding, 2013). This may explain why the magnitude of the bloom is weak and corresponds to low surface chlorophyll $a$ concentration at this period of the season. This weak coccolithophore bloom drives most $(85.2 \%)$ of the annual PIC export that appears very low (6.6 mmol m ${ }^{-2} \mathrm{y}^{-1}$ ) compared to coccolith fine fraction export from the temperate ocean $\left(0.2-0.8 \mathrm{~mol} \mathrm{~m}^{-2} \mathrm{y}^{-1}\right.$, Ziveri et al., 2007).

\subsection{Southern Ocean carbonate counter pump affected by different planktonic calcifying organisms}

The annually-integrated PIC:POC export ratio of 0.07 (mol:mol) is close to the mean ratio for the global ocean $(0.06 \pm 0.03$, Sarmiento et al., 2002) and appears much lower than the ratio found in sediment traps of the PFZ and the SAZ $(\sim 1$, from a data compilation by Salter et al., 2014). The annual POC export (98.2 $\mathrm{mmol} \mathrm{m}^{-2} \mathrm{yr}^{-1}$, Rembauville et al., 2015b) and the annual PIC export ( $6.6 \mathrm{mmol} \mathrm{m}^{-2} \mathrm{yr}^{-1}$ ) at station A3 allow us to estimate the strength of the carbonate counter pump: the reduction of the $\mathrm{CO}_{2}$ drawdown by the biological pump due to the $\mathrm{CO}_{2}$ production during the calcification process in the mixed layer (Frankignoulle et al., 1994; Zeebe, 2012; Salter et al., 2014). As the trap depth $(289 \mathrm{~m})$ was close to the winter mixed layer depth $(220 \mathrm{~m}$ in this region of the Southern Ocean (Park et al., 1998; de Boyer Montégut et al., 2004), POC fluxes were not corrected for attenuation with depth. The carbonate counter pump effect $\left(\mathrm{CC}_{\text {pump }}\right.$, \%) was calculated from the annual fluxes as $\mathrm{CC}_{\text {pump }}=\left(\mathrm{PIC}_{\text {flux }} \times \Psi\right) / \mathrm{POC}_{\text {flux }}$ $\times 100$. $\Psi$ is the mole of $\mathrm{CO}_{2}$ emitted by mole of $\mathrm{CO}_{3}{ }^{2-}$ precipitated during the calcification process and ranges $0.7-0.8$ for seawater at $5{ }^{\circ} \mathrm{C}$ and a $\mathrm{pCO}_{2}$ of $300-400 \mu \mathrm{atm}$ (Frankignoulle et al., 1994). The calculation leads to a $\mathrm{CC}_{\text {pump }}$ of $4.7-5.4 \%$ at station $\mathrm{A} 3$. This value is consistent with the previously reported value at the M6 site also located in the AAZ (1-4\%) and is significantly lower that the values in the PFZ at the M5 and M10 sites (6-32\%) reported in Salter et al. (2014).

In the PFZ downstream Crozet, foraminifers were significant contributors to the production and export of PIC (30-50\%), with a lower contribution of coccoliths (20\%) and pteropods (5\%, Salter et al., 2014). Conversely, foraminifers are minor contributors over the central Kerguelen plateau in the $A A Z(<15 \%$, Table 2). The similarity of the $\mathrm{CC}_{\text {pump }}$ between the M6 and $\mathrm{A} 3$ sites in the $\mathrm{AAZ}$ supports the idea that the position of productivity relative to the Polar Front (Salter et al., 2014) exerts a major control on the magnitude of the $\mathrm{CC}_{\text {pump }}$ through two processes: (1) changes in the relative abundance of heterotrophic calcifiers foraminifers/ pteropods to autotrophic coccolithophores, and (2) a change in the contribution of foraminifer species with different SNWs.

During the last two million years the glaciations have been characterized by lower $\mathrm{CO}_{2}$ concentration in the atmosphere that has been explained by a combination of both biology (strengthening of the biological pump) and physics of the Southern Ocean (Sigman and Boyle, 2000; Kohfeld et al., 2005; Robinson et al., 2005; Martínez-Botí et al., 2015). The higher efficiency of the biological pump was likely linked to higher deposition of eolian iron and more complete utilization of nutrients at high latitudes (Mahowald et al., 2006; Martínez-García et al., 2014). Our results from naturally fertilized Southern Ocean blooms suggest that the magnitude of the associated carbonate counter pump (Salter et al., 2014) depends not only on the dominant calcifying planktonic organisms (foraminifers versus coccolithophores), but also on the species assemblage that responds to the increase in primary production.

\section{Acknowledgements}

We thank Nathalie Leblond for the ICP-OES analyses. The authors are grateful to Michael Grelaud and Ignacio Villarroya for kind assistance during fine fraction elemental analyses. We thank two anonymous reviewers for their useful comments. This work was supported by the French research programme of INSU-CNRS LEFE-CYBER (Les enveloppes fluides et l'environnement - Cycles biogéochimiques, environnement et ressources), the French ANR (Agence Nationale de la Recherche, SIMI-6 programme, ANR-10BLAN-0614) and the Institute Polaire Paul Emile Victor (IPEV). P. Ziveri was funded through the Projects CGL2009-10806 and Unidades de Excelencia "María de Maeztu" 2015 (MDM2015-0552) (MinECo).

\section{References}

Archer, D., Maier-Reimer, E., 1994. Effect of deep-sea sedimentary calcite preservation on atmospheric $\mathrm{CO}_{2}$ concentration. Nature 367, 260-263. http://dx. doi.org/10.1038/367260a0.

Archer, D., Winguth, A., Lea, D., Mahowald, N., 2000. What caused the glacial/interglacial atmospheric $\mathrm{pCO}_{2}$ cycles? Rev. Geophys. 38, 159-189. http://dx.doi. org/10.1029/1999RG000066.

Armand, L.K., Cornet-Barthaux, V., Mosseri, J., Quéguiner, B., 2008. Late summer diatom biomass and community structure on and around the naturally ironfertilised Kerguelen Plateau in the Southern Ocean. Deep-Sea Res. II: Top. Stud. Oceanogr. 55, 653-676. http://dx.doi.org/10.1016/j.dsr2.2007.12.031.

Asioli, A., Langone, L., 1997. Relationship between recent Planktic Foraminifera and water mass properties in the Western Ross Sea (Antarctica). Geogr. Fis. Din. Quat. 20, 193-198.

Atkinson, D., 1994. Temperature and organism size - a biological law for ectotherms. Adv. Ecol. Res. 25, 1-58.

Bairbakhish, A.N., Bollmann, J., Sprengel, C., Thierstein, H.R., 1999. Disintegration of aggregates and coccospheres in sediment trap samples. Mar. Micropaleontol. 37, 219-223. http://dx.doi.org/10.1016/S0377-8398(99)00019-5.

Balch, W.M., Drapeau, D.T., Bowler, B.C., Lyczskowski, E., Booth, E.S., Alley, D., 2011 The contribution of coccolithophores to the optical and inorganic carbon budgets during the southern ocean gas exchange experiment: new evidence in support of the "Great calcite Belt" hypothesis. J. Geophys. Res. Oceans 116. http: //dx.doi.org/10.1029/2011JC006941.

Balch, W.M., Drapeau, D.T., Bowler, B.C., Lyczskowski, E.R., Lubelczyk, L.C., Painter, S C., Poulton, A.J., 2014. Surface biological, chemical, and optical properties of the Patagonian shelf coccolithophore bloom, the brightest Waters of the great calcite belt. Limnol. Oceanogr. 59, 1715-1732. http://dx.doi.org/10.4319/ lo.2014.59.5.1715. 
Balch, W.M., Gordon, H.R., Bowler, B.C., Drapeau, D.T., Booth, E.S., 2005. Calcium carbonate measurements in the surface global ocean based on moderate-resolution imaging Spectroradiometer data. J. Geophys. Res. Oceans, 110. http: //dx.doi.org/10.1029/2004JC002560.

Barker, S., Elderfield, H., 2002. Foraminiferal calcification response to glacial-interglacial Changes in atmospheric $\mathrm{CO}_{2}$. Science 297, 833-836. http://dx.doi.org/ 10.1126/science.1072815.

Beer, C.J., Schiebel, R., Wilson, P.A., 2010a. Testing planktic foraminiferal shell weight as a surface water [CO3 2-] proxy using plankton net samples. Geology 38, 103-106.

Beer, C.J., Schiebel, R., Wilson, P.A., 2010b. Technical note: on methodologies for determining the size-normalised weight of planktic foraminifera. Biogeosciences 7, 2193-2198. http://dx.doi.org/10.5194/bg-7-2193-2010.

Bergami, C., Capotondi, L., Langone, L., Giglio, F., Ravaioli, M., 2009. Distribution of living planktonic foraminifera in the Ross SEA and the pacific sector of the southern ocean (Antarctica). Mar. Micropaleontol. 73, 37-48. http://dx.doi.org/ 10.1016/j.marmicro.2009.06.007.

Bijma, J., Hönisch, B., Zeebe, R.E., 2002. Impact of the ocean carbonate chemistry on living foraminiferal shell weight: comment on "Carbonate ion concentration in glacial-age deep waters of the caribbean sea" by W.S. Broecker and E. Clark, Geochem. Geophys. Geosyst., 3, p. 1064. doi:10.1029/2002GC000388.

Bijma, J., Spero, H.J., Lea, D.W., 1999. Reassessing foraminiferal stable isotope geochemistry: impact of the oceanic carbonate system (experimental results). In: Fischer, D.G., Wefer, P.D.G. (Eds.), Use of Proxies in Paleoceanography. Springer, Berlin, Heidelberg, pp. 489-512.

Blain, S., Quéguiner, B., Armand, L., Belviso, S., Bombled, B., Bopp, L., Bowie, A., Brunet, C., Brussaard, C., Carlotti, F., Christaki, U., Corbière, A., Durand, I., Ebersbach, F., Fuda, J.-L., Garcia, N., Gerringa, L., Griffiths, B., Guigue, C., Guillerm, C., Jacquet, S., Jeandel, C., Laan, P., Lefèvre, D., Lo Monaco, C., Malits, A., Mosseri, J., Obernosterer, I., Park, Y.-H., Picheral, M., Pondaven, P., Remenyi, T. Sandroni, V., Sarthou, G., Savoye, N., Scouarnec, L., Souhaut, M., Thuiller, D., Timmermans, K., Trull, T., Uitz, J., van Beek, P., Veldhuis, M., Vincent, D., Viollier E., Vong, L., Wagener, T., 2007. Effect of natural iron fertilization on carbon sequestration in the southern ocean. Nature 446, 1070-1074. http://dx.doi.org $10.1038 /$ nature05700.

Blain, S., Sarthou, G., Laan, P., 2008. Distribution of dissolved iron during the natural iron-fertilization experiment KEOPS (Kerguelen plateau, southern ocean). Deep Sea Res. Part II Top. Stud. Oceanogr. 55, 594-605. http://dx.doi.org/10.1016/j. dsr2.2007.12.028, KEOPS: Kerguelen Ocean and Plateau compared Study.

Blain, S., Tréguer, P., Belviso, S., Bucciarelli, E., Denis, M., Desabre, S., Fiala, M., Martin Jézéquel, V., Le Fèvre, J., Mayzaud, P., Marty, J.-C., Razouls, S., 2001. A biogeochemical study of the island Mass effect in the context of the iron hypothesis: Kerguelen Islands Southern Ocean. Deep-Sea Res. I: Oceanogr. Res. Pap. 48 163-187. http://dx.doi.org/10.1016/S0967-0637(00)00047-9.

Bowie, A.R., van der Merwe, P., Quéroué, F., Trull, T., Fourquez, M., Planchon, F., Sarthou, G., Chever, F., Townsend, A.T., Obernosterer, I., Sallée, J.-B., Blain, S. 2015. Iron budgets for three distinct biogeochemical sites around the Kerguelen archipelago (Southern Ocean) during the natural fertilisation study, KEOPS-2. Biogeosciences 12, 4421-4445. http://dx.doi.org/10.5194/bg-12-4421-2015.

Boyd, P.W., 2002. Environmental factors controlling phytoplankton processes in the Southern Ocean1. J. Phycol. 38, 844-861. http://dx.doi.org/10.1046/ j.1529-8817.2002.t01-1-01203.x.

Brand, L.E., Sunda, W.G., Guillard, R.R.L., 1983. Limitation of marine phytoplankton reproductive rates by zinc, manganese, and iron1. Limnol. Oceanogr. 28 , 1182-1198. http://dx.doi.org/10.4319/lo.1983.28.6.1182.

Broecker, W.S., Clark, E., 2001. Reevaluation of the $\mathrm{CaCO}_{3}$ size index paleocarbonate ion proxy. Paleoceanography 16, 669-671. http://dx.doi.org/10.1029/ 2001PA000660.

Broerse, A.T.C., Ziveri, P., van Hinte, J.E., Honjo, S., 2000. Coccolithophore export production, species composition, and coccolith- $\mathrm{CaCO}_{3}$ fluxes in the NE Atlantic $\left(34^{\circ} \mathrm{N} 21^{\circ} \mathrm{W}\right.$ and $48^{\circ} \mathrm{N} 21^{\circ} \mathrm{W}$ ). Deep Sea Res. II: Top. Stud. Oceanogr. 47, 1877-1905. http://dx.doi.org/10.1016/S0967-0645(00)00010-2.

de Boyer Montégut, C., Madec, G., Fischer, A.S., Lazar, A., Iudicone, D., 2004. Mixed layer depth over the global ocean: an examination of profile data and a profilebased climatology. J. Geophys. Res. Oceans 109, C12003. http://dx.doi.org/ 10.1029/2004JC002378.

de Villiers, S., 2004. Optimum growth conditions as opposed to calcite saturation as a control on the calcification rate and shell-weight of marine foraminifera. Mar. Biol. 144, 45-49. http://dx.doi.org/10.1007/s00227-003-1183-8.

Dickson, A.G., Sabine, C.L., Christian, J.R., 2007. Guide to Best Practices for Ocean $\mathrm{CO}_{2}$ Measurements. PICES Special Publication 3.

Donner, B., Wefer, G., 1994. Flux and stable isotope composition of Neogloboquadrina pachyderma and other planktonic foraminifers in the southern ocean (Atlantic sector). Deep Sea Res. I: Oceanogr. Res. Pap. 41, 1733-1743. http://dx. doi.org/10.1016/0967-0637(94)90070-1.

Fielding, S.R., 2013. Emiliania huxleyi specific growth rate dependence on temperature. Limnol. Oceanogr. 58, 663-666. http://dx.doi.org/10.4319/ 0.2013 .58 .2 .0663$.

Findlay, C.S., Giraudeau, J., 2000. Extant calcareous nannoplankton in the Australian sector of the southern ocean (austral summers 1994 and 1995). Mar. Micropaleontol. 40, 417-439. http://dx.doi.org/10.1016/S0377-8398(00)00046-3.

Fisher, N.S., Honjo, S., 1989. Intraspecific differences in temperature and salinity responses in the coccolithophore Emiliania huxleyi. Biol. Ocean. 6, 355-361. http://dx.doi.org/10.1080/01965581.1988.10749537.

Frankignoulle, M., Canon, C. Gattudo, J.-P., 1994. Marine calcification as a source of carbon dioxide : positive deedback of increasing atmospheric $\mathrm{CO}_{2}$. Limnol.
Oceanogr. 39, 458-462.

Garcia, H.E., Locarini, R.A., Boyer, T.P., Antonov, J.I., Baranova, O.K., Zweng, M.M., Reagan, J.R., Johnson, D.R., 2013. World Ocean Atlas 2013, In: S. Levitus(Eds.), A. Mishonov Technical Ed., Dissolved Inorganic Nutrients (phosphate, nitrate, silicate), Vol. 4

Gordon, H.R., Boynton, G.C., Balch, W.M., Groom, S.B., Harbour, D.S., Smyth, T.J., 2001. Retrieval of coccolithophore calcite concentration from SeaWiFS imagery. Geophys. Res. Lett. 28, 1587-1590. http://dx.doi.org/10.1029/2000GL012025.

Gordon, H.R., McCluney, W.R., 1975. Estimation of the depth of sunlight penetration in the SEA for remote sensing. Appl. Opt. 14, 413-416.

Hemleben, C., Spindler, O., Anderson, R., 1989. Modern Planktonic Foraminifera, ed. Springer-Verlag, New-York.

Holligan, P.M., Charalampopoulou, A., Hutson, R., 2010. Seasonal distributions of the coccolithophore, Emiliania huxleyi, and of particulate inorganic carbon in surface waters of the scotia Sea. J. Mar. Syst. 82, 195-205. http://dx.doi.org/ 10.1016/j.jmarsys.2010.05.007.

Holligan, P.M., Viollier, M., Harbour, D.S., Camus, P., Champagne-Philippe, M., 1983. Satellite and ship studies of coccolithophore production along a continental shelf edge. Nature 304, 339-342. http://dx.doi.org/10.1038/304339a0.

Honjo, S., Manganini, S.J., Krishfield, R.A., Francois, R., 2008. Particulate organic carbon fluxes to the ocean interior and factors controlling the biological pump: a synthesis of global sediment trap programs since 1983. Prog. Oceanogr. 76, 217-285. http://dx.doi.org/10.1016/j.pocean.2007.11.003.

Hopkins, J., Henson, S.A., Painter, S.C., Tyrrell, T., Poulton, A.J., 2015. Phenological characteristics of global coccolithophore blooms. Glob. Biogeochem. Cycles 29. http://dx.doi.org/10.1002/2014GB004919.

Hunt, B.P.V., Pakhomov, E.A., Hosie, G.W., Siegel, V., Ward, P., Bernard, K., 2008 Pteropods in southern ocean ecosystems. Prog. Oceanogr. 78, 193-221. http: //dx.doi.org/10.1016/j.pocean.2008.06.001.

Jonkers, L., Kučera, M., 2015. Global analysis of seasonality in the shell flux of extant planktonic Foraminifera. Biogeosciences 12, 2207-2226. http://dx.doi.org/ 10.5194/bg-12-2207-2015.

Key, R.M., Kozyr, A., Sabine, C.L., Lee, K., Wanninkhof, R., Bullister, J.L., Feely, R.A Millero, F.J., Mordy, C., Peng, T.-H., 2004. A global ocean carbon climatology: results from global data analysis project (GLODAP). Glob. Biogeochem. Cycles 18, GB4031. http://dx.doi.org/10.1029/2004GB002247.

King, A.L., Howard, W.R., 2003. Planktonic foraminiferal flux seasonality in subantarctic sediment traps: a test for paleoclimate reconstructions. Paleoceanography 18, 1019. http://dx.doi.org/10.1029/2002PA000839.

Klaas, C., 2001. Spring distribution of larger $(>64 \mu \mathrm{m})$ protozoans in the Atlantic sector of the southern ocean. Deep-Sea Res. I: Oceanogr. Res. Pap. 48, 1627-1649. http://dx.doi.org/10.1016/S0967-0637(00)00088-1.

Kohfeld, K.E., Quéré, C.L., Harrison, S.P., Anderson, R.F., 2005. Role of marine biology in glacial-interglacial $\mathrm{CO}_{2}$ cycles. Science 308, 74-78. http://dx.doi.org/10.1126/ science. 1105375

Korb, R.E., Whitehouse, M.J., Atkinson, A., Thorpe, S.E., 2008. Magnitude and maintenance of the phytoplankton bloom at South Georgia: a naturally ironreplete environment. Mar. Ecol. Prog. Ser. 368, 75-91. http://dx.doi.org/ $10.3354 /$ meps07525.

Kuroyanagi, A., Kawahata, H., 2004. Vertical distribution of living planktonic foraminifera in the seas around Japan. Mar. Micropaleontol. 53, 173-196. http://dx. doi.org/10.1016/j.marmicro.2004.06.001.

Lochte, K., Ducklow, H.W., Fasham, M.J.R., Stienen, C., 1993. Plankton succession and carbon cycling at 47-degrees-N-20-degrees-W during the Jgofs north-Atlantic bloom experiment. Deep-Sea Res. II: Top. Stud. Oceanogr. 40, 91-114.

Lohmann, G.P., 1995. A model for variation in the chemistry of planktonic foraminifera due to secondary calcification and selective dissolution. Paleoceanography 10, 445-457. http://dx.doi.org/10.1029/95PA00059.

Lombard, F., Labeyrie, L., Michel, E., Bopp, L., Cortijo, E., Retailleau, S., Howa, H., Jorissen, F., 2011. Modelling planktic foraminifer growth and distribution using an ecophysiological multi-species approach. Biogeosciences 8, 853-873. http: //dx.doi.org/10.5194/bg-8-853-2011.

Lombard, F., Labeyrie, L., Michel, E., Spero, H.J., Lea, D.W., 2009. Modelling the temperature dependent growth rates of planktic foraminifera Mar Micropaleontol. 70, 1-7. http://dx.doi.org/10.1016/j.marmicro.2008.09.004.

Mahowald, N.M., Muhs, D.R., Levis, S., Rasch, P.J., Yoshioka, M., Zender, C.S., Luo, C., 2006. Change in atmospheric mineral aerosols in response to climate: last glacial period, preindustrial, modern, and doubled carbon dioxide climates. J. Geophys. Res. Atmos. 111, D10202. http://dx.doi.org/10.1029/2005JD006653.

Margalef, R., 1978. Life-forms of phytoplankton as survival alternatives in an unstable environment. Oceanol. Acta 1, 493-509.

Marshall, B.J., Thunell, R.C., Henehan, M.J., Astor, Y., Wejnert, K.E., 2013. Planktonic foraminiferal area density as a proxy for carbonate ion concentration: a calibration study using the Cariaco basin ocean time series. Paleoceanography 28 , 363-376. http://dx.doi.org/10.1002/palo.20034.

Martínez-Botí, M.A., Marino, G., Foster, G.L., Ziveri, P., Henehan, M.J., Rae, J.W.B., Mortyn, P.G., Vance, D., 2015. Boron isotope evidence for oceanic carbon dioxide leakage during the last deglaciation. Nature 518, 219-222. http://dx.doi.org/ 10.1038 /nature14155.

Martínez-García, A., Sigman, D.M., Ren, H., Anderson, R.F., Straub, M., Hodell, D.A., Jaccard, S.L., Eglinton, T.I., Haug, G.H., 2014. Iron fertilization of the subantarctic ocean during the last ICE age. Science 343, 1347-1350. http://dx.doi.org/ 10.1126/science.1246848.

Martin, J.H., Gordon, R.M., Fitzwater, S.E., 1990. Iron in Antarctic waters. Nature 345, 156-158. http://dx.doi.org/10.1038/345156a0.

Matsumoto, K., Sarmiento, J.L., Brzezinski, M.A., 2002. Silicic acid leakage from the 
southern ocean: a possible explanation for glacial atmospheric $\mathrm{pCO}_{2}$. Glob. Biogeochem. Cycles 16. http://dx.doi.org/10.1029/2001GB001442.

Meilland, J., 2015. The Role of Planktonic foraminifera in the Marine Carbon Cycle at High Latitudes (Souther, Indian Ocean) (Ph.D Thesis). University of Angers, France.

McIntyre, A., Bé, A.W.H., Roche, M.B., 1970. Modern pacific coccolithophorida: a paleontological thermometer. Trans. N. Y. Acad. Sci. 32, 720-731. http://dx.doi. org/10.1111/j.2164-0947.1970.tb02746.x.

Minas, H.J., Minas, M., Packard, T.T., 1986. Productivity in upwelling areas deduced from hydrographic and chemical fields. Limnol. Oceanogr. 31, 1182-1206. http: //dx.doi.org/10.4319/lo.1986.31.6.1182.

Minas, H., Minas, M., 1992. Net community production in High nutrient-low chlorophyll waters of the tropical and Antarctic oceans-grazing vs iron hypothesis. Oceanol. Acta 15, 145-162.

Mortyn, P.G., Charles, C.D., 2003. Planktonic foraminiferal depth habitat and $\delta 180$ calibrations: plankton TOW results from the Atlantic sector of the southern ocean. Paleoceanography 18, 1037. http://dx.doi.org/10.1029/2001PA000637.

Mosseri, J., Quéguiner, B., Armand, L., Cornet-Barthaux, V., 2008. Impact of iron on silicon utilization by diatoms in the southern ocean: a case study of Si/N cycle decoupling in a naturally iron-enriched area. Deep-Sea Res. II: Top. Stud. Oceangr. 55, 801-819. http://dx.doi.org/10.1016/j.dsr2.2007.12.003.

Movellan, A., Schiebel, R., Zubkov, M.V., Smyth, A., Howa, H., 2012. Protein biomass quantification of unbroken individual foraminifers using nano-spectrophotometry. Biogeosciences 9, 3613-3623. http://dx.doi.org/10.5194/ bg-9-3613-2012.

Moy, A.D., Howard, W.R., Bray, S.G., Trull, T.W., 2009. Reduced calcification in modern southern ocean planktonic foraminifera. Nat. Geosci. 2, 276-280. http: //dx.doi.org/10.1038/ngeo460.

Muggli, D.L., Harrison, P.J., 1997. Effects of iron on two oceanic phytoplankters grown in natural NE subarctic pacific seawater with no artificial chelators present. J. Exp. Mar. Biol. Ecol. 212, 225-237. http://dx.doi.org/10.1016/ S0022-0981(96)02752-9.

Northcote, L.C., Neil, H.L., 2005. Seasonal variations in foraminiferal flux in the southern ocean, Campbell Plateau, New Zealand. Mar. Micropaleontol. 56, 122-137. http://dx.doi.org/10.1016/j.marmicro.2005.05.001.

Orr, J.C., Epitalon, J.-M., Gattuso, J.-P., 2015. Comparison of ten packages that compute ocean carbonate chemistry. Biogeosciences 12, 1483-1510. http://dx. doi.org/10.5194/bg-12-1483-2015.

Park, Y.-H., Charriaud, E., Pino, D.R., Jeandel, C., 1998. Seasonal and interannual variability of the mixed layer properties and steric height at station KERFIX, southwest of Kerguelen. J. Mar. Syst. 17, 571-586. http://dx.doi.org/10.1016/ S0924-7963(98)00065-7.

Park, Y.-H., Durand, I., Kestenare, E., Rougier, G., Zhou, M., d'Ovidio, F., Cotté, C., Lee, J.-H., 2014. Polar Front around the Kerguelen Islands: An up-to-date determination and associated circulation of surface/subsurface waters. J. Geophys. Res.Oceans 119, 6575-6592, http://dx.doi.org/10.1002/2014JC010061.

Park, Y.-H., Gamberoni, L., Charriaud, E., 1993. Frontal structure, water masses, and circulation in the Crozet basin. J. Geophys. Res. Oceans 98, 12361-12385. http: //dx.doi.org/10.1029/93JC00938.

Park, Y.-H., Roquet, F., Durand, I., Fuda, J.-L., 2008. Large-scale circulation over and around the northern Kerguelen plateau. Deep Sea Res. II: Top. Stud. Oceangr. 55, 566-581. http://dx.doi.org/10.1016/j.dsr2.2007.12.030.

Planquette, H., Statham, P.J., Fones, G.R., Charette, M.A., Moore, C.M., Salter, I., Nédélec, F.H. Taylor, S.L. French, M., Baker, A.R, Mahowald, N., Jickells, T.D., 2007. Dissolved iron in the vicinity of the Crozet Islands, Southern Ocean. Deep Sea Res. II: Top. Stud. Oceangr. 54, 1999-2019. http://dx.doi.org/10.1016/j. dsr2.2007.06.019.

Pollard, R., Lucas, M., Read, J., 2002. Physical controls on biogeochemical zonation in the southern ocean. Deep Sea Res. II: Top. Stud. Oceangr. 49, 3289-3305. http: //dx.doi.org/10.1016/S0967-0645(02)00084-X.

Pollard, R., Sanders, R., Lucas, M., Statham, P., 2007. The Crozet natural iron bloom and export experiment (CROZEX). Deep-Sea Res. II: Top. Stud. Oceangr. 54, 1905-1914. http://dx.doi.org/10.1016/j.dsr2.2007.07.023.

Pollard, R.T., Venables, H.J., Read, J.F., Allen, J.T., 2007. Large-scale circulation around the Crozet plateau controls an annual phytoplankton bloom in the Crozet basin. Deep Sea Res. II: Top. Stud. Oceangr. 54, 1915-1929. http://dx.doi.org/10.1016/j. dsr2.2007.06.012.

Quéguiner, B., 2013. Iron fertilization and the structure of planktonic communities in high nutrient regions of the southern ocean. Deep-Sea Res. II: Top. Stud. Oceangr. 90, 43-54. http://dx.doi.org/10.1016/j.dsr2.2012.07.024.

Rembauville, M., Blain, S., Armand, L., Quéguiner, B., Salter, I., 2015a. Export fluxes in a naturally iron-fertilized area of the southern ocean - Part 2: importance of diatom resting spores and faecal pellets for export. Biogeosciences 12 , 3171-3195. http://dx.doi.org/10.5194/bg-12-3171-2015.

Rembauville, M., Salter, I., Leblond, N., Gueneugues, A., Blain, S., 2015b. Export fluxes in a naturally iron-fertilized area of the southern ocean - Part 1: seasonal dynamics of particulate organic carbon export from a moored sediment trap. Biogeosciences 12, 3153-3170. http://dx.doi.org/10.5194/bg-12-3153-2015.

Reynolds, R.W., Smith, T.M., Liu, C., Chelton, D.B., Casey, K.S., Schlax, M.G., 2007. Daily high-resolution-blended analyses for SEA surface temperature. J. Clim. 20, 5473-5496. http://dx.doi.org/10.1175/2007JCLI1824.1.

Robinson, R.S., Sigman, D.M., DiFiore, P.J., Rohde, M.M., Mashiotta, T.A., Lea, D.W., 2005. Diatom-bound 15N/14N: new support for enhanced nutrient consumption in the ICE age subantarctic. Paleoceanography 20, PA3003. http://dx.doi. org/10.1029/2004PA001114.

Saavedra-Pellitero, M., Baumann, K.-H., Flores, J.-A., Gersonde, R., 2014.
Biogeographic distribution of living coccolithophores in the pacific sector of the southern ocean. Mar. Micropaleontol. 109, 1-20. http://dx.doi.org/10.1016/j. marmicro.2014.03.003.

Sadeghi, A., Dinter, T., Vountas, M., Taylor, B., Altenburg-Soppa, M., Bracher, A., 2012. Remote sensing of coccolithophore blooms in selected oceanic regions using the phytoDOAS method applied to hyper-spectral satellite data. Biogeosciences 9, 2127-2143. http://dx.doi.org/10.5194/bg-9-2127-2012.

Salter, I., Kemp, A.E.S., Moore, C.M., Lampitt, R.S., Wolff, G.A., Holtvoeth, J., 2012. Diatom resting spore ecology drives enhanced carbon export from a naturally iron-fertilized bloom in the southern ocean. Glob. Biogeochem. Cycles 26, GB1014. http://dx.doi.org/10.1029/2010GB003977.

Salter, I., Schiebel, R., Ziveri, P., Movellan, A., Lampitt, R., Wolff, G.A., 2014. Carbonate counter pump stimulated by natural iron fertilization in the polar frontal zone. Nat. Geosci. 7, 885-889. http://dx.doi.org/10.1038/ngeo2285.

Sarmiento, J.L., Dunne, J., Gnanadesikan, A., Key, R.M., Matsumoto, K., Slater, R., 2002. A new estimate of the $\mathrm{CaCO}_{3}$ to organic carbon export ratio. Glob. Biogeochem. Cycles 16, 1107. http://dx.doi.org/10.1029/2002GB001919.

Sarmiento, J.L., Toggweiler, J.R., Najjar, R., Webb, D.J., Jenkins, W.J., Wunsch, C., Elderfield, H., Whitfield, M., Minster, J.-F., 1988. Ocean carbon-cycle dynamics and atmospheric $\mathrm{CO}_{2}$ [and discussion]. Philos. Trans. R. Soc. Lond. Math. Phys. Eng. Sci. 325, 3-21. http://dx.doi.org/10.1098/rsta.1988.0039.

Schiebel, R., 2002. Planktic foraminiferal sedimentation and the marine calcite budget. Glob. Biogeochem. Cycles 16, 1065. http://dx.doi.org/10.1029/ 2001GB001459.

Schiebel, R., Bijma, J., Hemleben, C., 1997. Population dynamics of the planktic foraminifer globigerina bulloides from the eastern north Atlantic. Deep-Sea Res. I: Oceanogr. Res. Pap. 44, 1701-1713. http://dx.doi.org/10.1016/S0967-0637(97) 00036-8.

Schiebel, R., Brupbacher, U., Schmidtko, S., Nausch, G., Waniek, J.J., Thierstein, H.-R., 2011. Spring coccolithophore production and dispersion in the temperate eastern north Atlantic ocean. J. Geophys. Res. Oceans 116, C08030. http://dx.doi. org/10.1029/2010JC006841.

Schiebel, R., Waniek, J., Bork, M., Hemleben, C., 2001. Planktic foraminiferal production stimulated by chlorophyll redistribution and entrainment of nutrients Deep-Sea Res. I: Oceanogr. Res. Pap. 48, 721-740. http://dx.doi.org/10.1016/ S0967-0637(00)00065-0.

Schmidt, D.N., Thierstein, H.R., Bollmann, J., Schiebel, R., 2004. Abiotic forcing of plankton evolution in the Cenozoic. Science 303, 207-210. http://dx.doi.org/ 10.1126/science.1090592.

Sigman, D.M., Boyle, E.A., 2000. Glacial/interglacial variations in atmospheric carbon dioxide. Nature 407, 859-869. http://dx.doi.org/10.1038/35038000.

Smetacek, V.S., 1985. Role of sinking in diatom life-history cycles: ecological, evolutionary and geological significance. Mar. Biol. 84, 239-251. http://dx.doi.org/ 10.1007/BF00392493.

Stoll, H.M., Ziveri, P., Shimizu, N., Conte, M., Theroux, S., 2007. Relationship between coccolith Sr/CA ratios and coccolithophore production and export in the Arabian Sea and sargasso Sea. Deep-Sea Res. Part II Top. Stud. Oceanogr. 54, 581-600. http://dx.doi.org/10.1016/j.dsr2.2007.01.003, The Role of Marine Organic Carbon and Calcite Fluxes in Driving Global Climate Change, Past and Future.

Strzepek, R.F., Hunter, K.A., Frew, R.D., Harrison, P.J., Boyd, P.W., 2012. Iron-light interactions differ in southern ocean phytoplankton. Limnol. Oceanogr. 57, 1182-1200. http://dx.doi.org/10.4319/lo.2012.57.4.1182.

Sunda, W.G., Huntsman, S.A., 1995. Iron uptake and growth limitation in oceanic and coastal phytoplankton. Mar. Chem. 50, 189-206. http://dx.doi.org/10.1016 0304-4203(95)00035-P, The Chemistry of Iron in Seawater and its Interaction with Phytoplankton.

Tarling, G.A., Ward, P., Atkinson, A., Collins, M.A., Murphy, E.J., 2012. DISCOVERY 2010: spatial and temporal variability in a dynamic polar ecosystem. Deep-Sea Res. II: Top. Stud. Oceangr. 59-60, 1-13. http://dx.doi.org/10.1016/j. dsr2.2011.10.001.

Thunell, R., Pride, C., Ziveri, P., Muller-Karger, F., Sancetta, C., Murray, D., 1996. Plankton response to physical forcing in the gulf of California. J. Plankton Res. 18, 2017-2026. http://dx.doi.org/10.1093/plankt/18.11.2017.

Townsend, D.W., Keller, M.D., Holligan, P.M., Ackleson, S.G., Balch, W.M., 1994 Blooms of the coccolithophore Emiliania huxleyi with respect to hydrography in the gulf of Maine. Cont. Shelf Res. 14, 979-1000. http://dx.doi.org/10.1016/ 0278-4343(94)90060-4.

Trull, T.W., Bray, S.G., Manganini, S.J., Honjo, S., François, R., 2001. Moored sediment trap measurements of carbon export in the subantarctic and polar frontal zones of the southern ocean, south of Australia. J. Geophys. Res. Oceans 106, 31489-31509. http://dx.doi.org/10.1029/2000JC000308.

Tyrrell, T., Merico, A., 2004. Emiliania huxleyi: bloom observations and the conditions that induce them. In: Thierstein, P.D.H.R., Young, D.J.R. (Eds.), Coccolithophores. Springer, Berlin, Heidelberg, pp. 75-97.

Volk, T., Hoffert, M.I., 1985. Ocean carbon pumps: analysis of relative strengths and efficiencies in ocean-driven atmospheric $\mathrm{CO}_{2}$ changes. In: Sundquist, E.T., Broecker, W.S. (Eds.), Geophysical Monograph SeriesAmerican Geophysical Union, Washington, D.C, pp. 99-110.

L., von Bertalanffy, 1960. Principles and theory of growth, in: Fundamental Aspects of Normal and Malignant Growth. Norwinksi, D.D.

Weiner, A.K.M., Weinkauf, M.F.G., Kurasawa, A., Darling, K.F., Kucera, M., 2015 Genetic and morphometric evidence for parallel evolution of the Globigerinella calida morphotype. Mar. Micropaleontol. 114, 19-35. http://dx.doi.org/10.1016 | j.marmicro.2014.10.003.

Weinkauf, M.F.G., Moller, T., Koch, M.C., Kučera, M., 2013. Calcification intensity in 
planktonic Foraminifera reflects ambient conditions irrespective of environmental stress. Biogeosciences 10, 6639-6655. http://dx.doi.org/10.5194/ bg-10-6639-2013.

Winter, A., Henderiks, J., Beaufort, L., Rickaby, R.E.M., Brown, C.W., 2014. Poleward expansion of the coccolithophore Emiliania huxleyi. J. Plankton Res. 36, 316-325. http://dx.doi.org/10.1093/plankt/fbt110.

Zeebe, R.E., 2012. History of seawater carbonate chemistry, atmospheric $\mathrm{CO}_{2}$, and ocean acidification. Annu. Rev. Earth Planet. Sci. 40, 141-165. http://dx.doi.org/ 10.1146/annurev-earth-042711-105521.

Ziveri, P., Broerse, A.T.C., van Hinte, J.E., Westbroek, P., Honjo, S., 2000. The fate of coccoliths at $48^{\circ} \mathrm{N} 21^{\circ} \mathrm{W}$, Northeastern Atlantic. Deep-Sea Res. II: Top. Stud. Oceangr. 47, 1853-1875. http://dx.doi.org/10.1016/S0967-0645(00)00009-6.

Ziveri, P., de Bernardi, B., Baumann, K.-H., Stoll, H.M., Mortyn, P.G., 2007. Sinking of coccolith carbonate and potential contribution to organic carbon ballasting in the deep ocean. Deep-Sea Res. II: Top. Stud. Oceanogr. 54, 659-675. http://dx. doi.org/10.1016/j.dsr2.2007.01.006, The Role of Marine Organic Carbon and Calcite Fluxes in Driving Global Climate Change, Past and Future.

Ziveri, P., Thunell, R.C., 2000. Coccolithophore export production in Guaymas basin, gulf of California: response to climate forcing. Deep-Sea Res. II: Top. Stud. Oceangr. 47, 2073-2100. http://dx.doi.org/10.1016/S0967-0645(00) 00017-5.

Ziveri, P., Thunell, R.C., Rio, D., 1995. Export production of coccolithophores in an upwelling region: results from San Pedro basin, southern California borderlands. Mar. Micropaleontol. 24, 335-358. http://dx.doi.org/10.1016/0377-8398 (94)00017-H. 